\title{
Pengaruh rutinitas di rumah terhadap kemandirian anak
}

\author{
Rosi Karmila, Siti Khosiah \& Fahmi \\ Universitas Sultan Ageng Tirtayasa \\ rosikarmila32@gmail.com
}

\begin{abstract}
This study aims to determine the effect of routine home activities on the independence of children aged 4-5 years in PAUD in Gunung Kencana sub-district, Lebak-Banten. The research used by researchers is quantitative research with survey research type with a sample of 32 teacher children aged 4-5 years who are in the Gunung Kencana sub-district. the results of the correlation coefficient of routine activities at home with independence of children aged 4-5 years showed a figure of 0.797 which means it has a strong level of relationship because it is in the category interval 0.60 to 0.779 . Which means that routine activities at home affect the child's independence. While the visible number of probabilities of routine activities at home to the independence of children aged 4-5 years is at a significant level of 0,000 $<0.05$ so that it can be said that the relationship between the two variables is significant.
\end{abstract}

Keywords: routinity, independence, todler

\begin{abstract}
Abstrak
Penelitian ini bertujuan untuk mengetahui pengaruh kegiatan rutin di rumah terhadap kemandirian anak usia 4-5 tahun di PAUD se-kecamatan Gunung Kencana, Lebak- Banten. penelitian yang digunakan oleh peneliti adalah penelitian kuantitatif dengan jenis penelitian survei dengan sampel 32 guru anak usia 4-5 tahun yang berada di kecamatan Gunung Kencana. hasil koefisien korelasi kegiatan rutin di rumah dengan kemandirian anak usia 4-5 tahun menunjukkan angka sebesar 0,797 yang berarti memiliki tingkat hubungan yang kuat karena berada pada interval kategori 0,60 s/d 0,779. Yang Artinya kegiatan rutin di rumah berpengaruh terhadap kemandirian anak. Sedangkan terlihat angka probabilitas kegiatan rutin di rumah terhadap kemandirian anak usia 4-5 tahun adalah dalam taraf signifikan sebesar 0,000<0,05 sehingga bisa dikatakan bahwa hubungan kedua variabel signifikan.
\end{abstract}

Kata kunci: rutinitas, kemandirian, usia dini 


\section{Pendahuluan}

Salah satu perilaku yang harus diperkenalkan kepada anak sedini mungkin adalah kemandirian. Dengan kemandirian akan menghindarkan anak dari sifat ketergantungan pada orang lain dan yang terpenting dalam menumbuhkan keberanian anak dilakukan dengan memberikan motivasi pada anak untuk terus mengetahui pengetahuanpengetahuan baru melalui pengawasan orang tua.

Kemandirian pada anak-anak terlihat ketika anak menggunakan pikirannya sendiri dalam mengambil berbagai keputusan; dari memilih perlengkapan belajar yang ingin digunakannya, memilih taman bermain, dan sampai hal-hal yang lebih relatif rumit. Tumbuhnya kemandirian pada anak bersamaan dengan munculnya rasa takut (kekhawatiran) dalam berbagai bentuk dan intensitasnya yang berbeda-beda. Rasa takut dalam hal yang wajar dapat berfungsi sebagai "emosi perlindungan" (protective emotional) bagi anak-anak, yang memungkinnya mengetahui kapan waktunya meminta pertolongan kepada orang dewasa.

Dalam upaya mendorong tumbuhnya kemandirian anak sejak dini ini menyarankan agar orang tua, guru dan lingkungan sekitarnya perlu memberikan gambaran yang bisa membentuk perilaku mandiri anak dengan konsep Developmentally Appropriate Practice (DAP) adalah metode pembelajaran yang menyenangkan bagi anak dan selain itu sesuai dengan perkembangan anak. Salah satu pembelajaran untuk mengembangkan keterampilan sikap mandiri anak dengan aktivitas yang sering anak lakukan secara langsung adalah kegiatan rutin di rumah misalnya makan, mandi, pakai baju, dan saat anak bangun tidur.

Menurut Gestwicki dalam Yus Anita (2011, hlm. 41) Developmentally Appropriate Practice adalah suatu kerangka berpikir atau framework, suatu filosofi, atau suatu pendekatan yang menunjukkan bagaimana caranya bekerja sama dengan anak-anak. Batasan ini menunjukkan bahwa DAP memiliki tiga fungsi, yaitu filosofi, pendekatan dan kerangka bekerja. DAP sebagai filosofi yaitu cara pandang terhadap anak-anak tentang anak sebagai individual dan bagian dari keluarga dan lingkungannya, DAP sebagai pendekatan yaitu memperlakukan anak-anak dalam pelaksanaan PAUD, dan DAP sebagai kerangka bekerja bagaimana caranya bekerja sama dengan anak-anak.

DAP adalah pendidikan yang patut dan menyenangkan sesuai dengan tahapan perkembangan anak, mencerminkan proses pembelajaran yang bersifat interaktif. Konsep DAP yang dikembangkan melalui beragam kegiatan yang sesuai dengan tahapan perkembangan anak menyebabkan anak memiliki pengalaman yang kongkret serta menyenangkan sehingga terjadinya kesadaran untuk belajar.

Penelitian yang dilakukan oleh Yuni Retnowati (2014) menggunakan metode kualitatif kasus di kota Yogyakarta menunjukkan hasil penelitian bahwa pola komunikasi lebih berperan dalam pembentukan kemandirian anak. Persamaan dan perbedaan antara 
penelitian peneliti dengan penelitian di atas adalah; persamaan dari penelitian ini adalah sama-sama meneliti tentang kemandirian lalu perbedaannya adalah penelitian di atas menggunakan metode kualitatif sedangkan penelitian ini menggunakan metode kuantitatif, untuk variabel $\mathrm{X}$ penelitian di atas membahas pola komunikasi sedangkan penelitian ini tentang kegiatan rutin di rumah.

\section{Metode Penelitian}

Metode yang digunakan dalam penelitian ini adalah dengan metode survei. dilaksanakan di PAUD Kecamatan Gunung Kencana Lebak-Banten. Penelitian ini dilakukan pada bulan Juni tahun 2020. Teknik yang digunakan dalam pengambilan sampel yaitu teknik purposive sampling . Purposive Sampling adalah teknik penentuan sampel dengan kriteria tertentu. Berdasarkan dari populasi berjumlah 19 PAUD Kecamatan Gunung Kencana Lebak- Banten, maka untuk sampel yang digunakan dalam penelitian ini yaitu 25 anak kelas A di PAUD yang berada di Kecamatan Gunung Kencana Lebak-Banten.

\section{A. Hasil}

\section{HASIL DAN PEMBAHASAN}

Berdasarkan teknik Purposive Sampling yang digunakan dalam penelitian yang menggunakan pengamatan video. Penelitian dilakukan pada bulan Juni 2020. Dalam penelitian terdapat dua variabel, yaitu variabel Kegiatan Rutin Di rumah (X) dan variabel Kemandirian Anak Usia -5 Tahun (Y), pengamatan terhadap 25 Anak Usia 4-5 tahun yang berada di PAUD Se-kecamatan Gunung Kencana. Adapun hasil data penelitian yang diperoleh yang berupa: (1) uji linearitas (2) uji regresi liniear sederhana dan (3) uji korelasi.

Tabel 1. Hasil Perhitungan Linearitas

\begin{tabular}{|c|c|c|c|c|c|c|c|}
\hline & & & $\begin{array}{c}\text { Sum of } \\
\text { Squares }\end{array}$ & Df & $\begin{array}{c}\text { Mean } \\
\text { Square }\end{array}$ & $\mathbf{F}$ & Sig. \\
\hline \multirow{5}{*}{$\begin{array}{c}\text { KEMANDIRIAN } \\
\text { ANAK }{ }^{*} \\
\text { KEGIATAN } \\
\text { RUTIN DI } \\
\text { RUMAH }\end{array}$} & \multirow{3}{*}{$\begin{array}{c}\text { Between } \\
\text { Groups }\end{array}$} & (Combined) & 164.375 & 9 & 18.264 & 7.254 & .001 \\
\hline & & Linearity & 124.639 & 1 & 124.639 & 49.502 & .000 \\
\hline & & $\begin{array}{l}\text { Deviation from } \\
\text { Linearity }\end{array}$ & 39.736 & 8 & 4.967 & 1.973 & .127 \\
\hline & \multicolumn{2}{|c|}{ Within Groups } & 35.250 & 14 & 2.518 & & \\
\hline & \multicolumn{2}{|c|}{ Total } & 199.625 & 23 & & & \\
\hline
\end{tabular}

Berdasarkan tabel 1 di atas, dapat disimpulkan bahwa nilai signifikasi sebesar 0,127. Kriteria perhitungan uji linieritas data yaitu jika nilai signifikasi $>0,05$ maka terdapat hubungan yang linier antara variabel bebas dan variabel terikat. Sedangkan jika nilai signifikasi < 0,05 maka tidak terdapat hubungan yang linier antara variabel bebas dan variabel terikat Berdasarkan tabel 1. di atas. Berdasarkan tabel tersebut dapat 
Pengaruh Kegiatan Rutin di Rumah Terhadap Kemandirian Anak

disimpulkan bahwa terdapat hubungan yang linear antara kegiatan rutin di rumah dengan kemandirian anak karena 0,127 > 0,05.

Tabel 2. Hasil Perhitungan linear sederhana

\begin{tabular}{ccccc}
\hline \multicolumn{5}{c}{ Model Summary } \\
\hline Model & $\mathrm{R}$ & R Square & Adjusted R Square & Std. Error of the Estimate \\
\hline $\mathbf{1}$ & $.797 \mathrm{a}$ & .635 & .619 & 1.80825 \\
\hline
\end{tabular}

Tabel 2 di atas menjelaskan besarnya nilai korelasi/hubungan (R) sebesar 0,797 . Dari output tersebut diperoleh (R Square) sebesar 0,635 yang mengandung arti bahwa pengaruh variabel $(\mathrm{X})$ kegiatan rutin di rumah (Y) kemandirian anak 63, 5\%.

Tabel 3. Hasil Perhitungan Koefisien

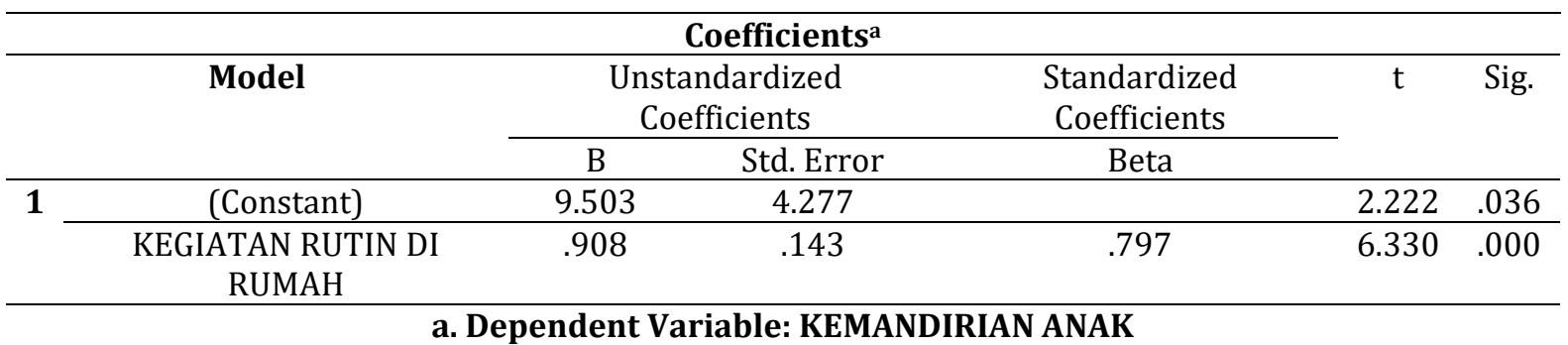

Berdasarkan nilai signifikan dari tabel 3, coefficients diperoleh nilai signifikan $0,000<0,005$. Sehingga dapat disimpulkan bahwa H0 ditolak dan H1 diterima, yang berarti bahwa "Ada pengaruh kegiatan rutin di rumah $(\mathrm{X})$ terhadap kemandirian anak (Y).

Tabel 4. Hasil perhitungan uji korelasi

\begin{tabular}{|c|c|c|c|}
\hline \multicolumn{4}{|c|}{ Correlations } \\
\hline & & $\begin{array}{c}\text { KEGIATAN RUTIN DI } \\
\text { RUMAH }\end{array}$ & $\begin{array}{l}\text { KEMANDIRIAN } \\
\text { ANAK }\end{array}$ \\
\hline \multirow[t]{3}{*}{$\begin{array}{c}\text { KEGIATAN RUTIN DI } \\
\text { RUMAH }\end{array}$} & $\begin{array}{c}\text { Pearson } \\
\text { Correlation }\end{array}$ & 1 & $.797^{* *}$ \\
\hline & Sig. (2-tailed) & & .000 \\
\hline & $\mathrm{N}$ & 25 & 25 \\
\hline \multirow[t]{3}{*}{ KEMANDIRIAN ANAK } & $\begin{array}{c}\text { Pearson } \\
\text { Correlation }\end{array}$ & $.797^{* *}$ & 1 \\
\hline & Sig. (2-tailed) & .000 & \\
\hline & $\mathrm{N}$ & 25 & 25 \\
\hline
\end{tabular}

Berdasarkan data pada tabel 4 di atas diketahui bahwa rhitung $<$ rtabel yaitu 0,797>0,396 yang berarti memiliki tingkat hubungan kuat berada pada interval 0,60 s/d 0,779, yang artinya kegiatan rutin di rumah berpengaruh dengan kemandirian anak dengan kategori kuat. 
Sedangkan terlihat angka probabilitas pengaruh kegiatan outbound terhadap kemandirian anak usia 4-5 tahu adalah dalam taraf signifikan 0,449 angka probabilitas $0,000<0,05$ sehingga bisa dikatakan bahwa ada pengaruh antara kedua variabel.

\section{B. Pembahasan}

Menurut Erikson dalam Desmita (2014, hlm. 185), kemandirian adalah usaha untuk melepaskan diri dari orang tua dengan maksud untuk menemukan dirinya melalui proses mencari ego, yaitu merupakan perkembangan ke arah individualitas yang mantap dan berdiri sendiri. Untuk mandiri seseorang membutuhkan kesempatan, dukungan, dan dorongan dari keluarga serta lingkungan di sekitarnya, agar mencapai kemandirian tersebut seseorang untuk tidak bergantung kepada orang tua ataupun orang lain. Sehingga anak menemukan egonya sendiri, kepribadian, dan karakter mereka yang akan menjadi penguat untuk setiap perilaku yang telah dilakukannya.

Menurut Gilmore dalam Hanifah dan Julia (2014, hlm. 64) menyatakan bahwa ciri-ciri kemandirian, dibagi menjadi 4 bagian diantarnya: (1) Ada rasa tanggung jawab, (2) Memiliki pertimbangan dalam menilai problem yang dihadapi secara intelegent. (3) Adanya perasaan aman bila memiliki pendapat yang berbeda dengan orang lain. (4) Adanya sikap kreatif sehingga menghasilkan ide yang berguna bagi orang lain.

Karakteristik dapat dijabarkan dalam empat tahap sebagai berikut: (1) Mencari orang lain (orang tua, ahli, guru, dan teman sejawat) untuk meminta bantuan menyelesaikan tugas tertentu. (2) Melakukan sendiri melalui arahan dan nasihat dari orang lain. (3) Melakukan latihan sendiri secara berulang-ulang melalui prosedur dan langkah-langkah penyelesaian. (4) Mengembangkan dan menciptakan cara lain untuk menyelesaikan tugas dengan baik (Yaumi, 2016, hlm. 100). Ada sejumlah faktor yang mempengaruhi perkembangan kemandirian, yaitu: (1) Gen atau Keturunan orang tua.(2) Pola asuh orang tua.(3) Sistem pendidikan di sekolah. (4) Sistem kehidupan masyarakat (Asrori, 2007, hlm. 137).

Menurut Peter Kline dalam Rosalina (2014, hlm. 162) langkah-langkah penerapan Strategi developmentally appropriate practice adalah: (1) Menciptakan lingkungan belajar yang dapat membuat anak asyik dalam pengalaman belajar, yaitu dengan melibatkan aspek fisiologi anak. Misalnya dengan games (kegiatan yang menyenangkan) akan melibatkan seluruh aspek fisik, emosi, sosial dan kognitif anak secara bersamaan (simultan). (2) Menciptakan kurikulum yang dapat menimbulkan minat anak dan kontekstual, sehingga anak menangkap makna atau dari apa yang dipelajarinya. (3) Menciptakan suasana belajar yang bebas tekanan dan ancaman, tetapi tetap menantang bagi anak untuk mencari tahn lebih banyak.(4) Menyampaikan materi. (5) Berikan mata pelajaran dengan melibatkan pengalaman konkret, terutama dalam pemecahan masalah, karena proses belajar paling efektif bukan dengan ceramah, tetapi dengan memberikan pengalaman nyata. 


\section{Kesimpulan}

Berdasarkan hasil penelitian dan pembahasan yang diperoleh tentang pengaruh kegiatan rutin di rumah terhadap kemandirian anak, dapat diambil kesimpulan bahwa terdapat pengaruh yang signifikan kegiatan rutin di rumah terhadap kemandirian anak usia 4-5 tahun di PAUD se-kecamatan Gunung Kencana.

\section{Daftar Pustaka}

Asrori, M. (2007). Psikologi pembelajaran. CV Wacana Prima.

Desmita. (2014). Psikologi Perkembangan Peserta Didik. PT. Remaja Rosdakarya.

Hanifah, N., \& Julia, J. (2014). Prosiding Seminar Nasional Pendidikan Dasar Membedah Anatomi Kurikulum 2013 untuk Membangun Masa Depan Pendidikan yang Lebih Baik. UPI Sumedang Press.

Retnowati, Y. (2014). Pola Komunikasi Orangtua Tunggal Dalam Membentuk Kemandirian Anak (Kasus Di Kota Yogyakarta). Jurnal Ilmu Komunikasi, 6(3), 199211.

Rosalina, R., Djahir, Y., \& Fitriyanti, F. (2014). Pengaruh Strategi Developmentally Appropriate Practice Terhadap Hasil Belajar Siswa Pada Mata Pelajaran IPS dl SMP Negeri 1 Tanjung Batu. Jurnal PROFIT Kajian Pendidikan Ekonomi dan Ilmu Ekonomi, 1(2), 157-168. https://doi.org/10.36706/jp.v1i2.5606

Yaumi, M. (2016). Pendidikan karakter: Landasan, pilar \& implementasi. Prenada Media.

Yus, A. (2011). Model pendidikan anak usia dini. Kencana. 